\title{
ТУРИСТИЧЕСКОЕ БЮРО «СПУТНИК»: РОЛЬ В РАЗВИТИИ МЕЖДУНАРОДНЫХ МОЛОДЕЖНЫХ ОБМЕНОВ
}

\author{
Ю. С. Путрик \\ Московский гуманитарный университет
}

Аннотация: В статье дается историческая справка о туристическом бюро «Спутник», созданном комсомолом в 1958 г., анализируется его опыт международной деятельности.

Ключевые слова: комсомол; «Спутник»; туризм; история СССР; международное сотрудничество; молодежь

\section{TRAVEL AGENCY “SPUTNIK": ITS ROLE IN THE DEVELOPMENT OF INTERNATIONAL STUDENT EXCHANGE}

\author{
Yu. S. Putrik \\ Moscow University for the Humanities
}

\begin{abstract}
The paper gives historical background of the travel agency "Sputnik", established by the Komsomol in 1958. It also analyses its experience in international activities.
\end{abstract}

Keywords: Komsomol; "Sputnik"; tourism; history of the USSR; international cooperation; youth

Среди многочисленных туристических компаний России далеко не последней в наши дни является туроператорская компания «Спутник», возникшая из недр комсомола в далеком 1958 г., являющаяся и сегодня вполне современной и модной компанией с инновационными разработками, позволяющими занимать почетное место среди лидеров туристического рынка. «Спутник» пришел к нам в сегодняшний день из СССР и родился он на мощной волне хрущевской оттепели и комсомольского энтузиазма, когда деятельность ВЛКСМ вышла на международный уровень и возникла необходимость все более и более активно развивать международные молодежные обмены между различными странами и в первую очередь между странами социалистического лагеря.

В нынешнем, 2018 году, «Спутник» отмечает свой 60-летний юбилей. В такие даты вполне уместно и даже необходимо обратиться к истории этой 
организации, которая не только связана с молодежным движением в советский, но стала частью российской и международной туристской индустрии. Активизация мирового туризма в конце 1950 - 1960-х годах не обошла стороной Советский Союз. Именно в этот период появляются термины «туристский бум», «туристская индустрия». В то время в СССР уже активно работали две мощные организации - государственная компания «Интурист» и Центральный совет по туризму и экскурсиям ВЦСПС, т. е в сфере профсоюзов. В туристские путешествия в нашей стране в этот период вовлекается все больше молодежи. В 1957 году в Москве проходил VI Всемирный фестиваль молодежи и студентов. Штаб организации этого грандиозного мероприятия и стал основой будущей специализированной молодежной туристской организации. 3 июня 1958 года появилось Распоряжение Совета Министров СССР о возможных направлениях деятельности новой туристской организации и льготах для молодых туристов.

А уже 24 июня того же года секретариат ЦК ВЛКСМ принял постановление «Об организации туристского обмена с зарубежными молодежными организациями» (далее БММТ «Спутник»). Был утвержден Устав Бюро международного молодежного туризма «Спутник». Согласно этому Уставу БММТ «Спутник» действовало как хозрасчетная организация при Комитете молодежных организаций СССР и на первом этапе занималось преимущественно международными молодежными туристскими обменами, а после 1963 года организация стала планировать, разрабатывать, и осуществлять путешествия юношей и девушек по туристским маршрутам внутри страны.

Стала формироваться система предоставления советской и иностранной молодежи разнообразных возможностей для путешествий, активного познавательного и оздоровительного отдыха. Все это было призвано способствовать укреплению мира, дружбы и взаимопонимания, установлению широких контактов советской молодежи со своими зарубежными сверстниками, а также разнообразному и полноценному отдыху советской молодежи. в процессе путешествий и экскурсий по СССР.

С этого периода БММТ «Спутник» стал активно и динамично развиваться. Из года в год увеличивались объемы зарубежных и внутрисоюзных туристских путешествий, росли показатели приема и обслуживания иностранных делегаций и туристских групп. При этом в тогдашних условиях двухполярного мира и противостояния двух систем - социалистической и капиталистической, особое внимание уделялось социально-политической направленности: подчеркиванию при обслуживании иностранных молодежных групп преимуществ социалистического строя перед капиталистическим, воспитанию патриотизма у советской молодежи.

Тут важно отметить, что туризм в СССР преследовал, конечно же, и по- 
Научные труды Московского гуманитарного университета 2018 № 6

литические цели, а в условиях ограниченности широких международных обменов служи значимым каналом для разведывательных целей в период противостояния двух политических систем. Так, В. К. Криворученко в своей книге «Месяц в Штатах» рассказывает, как он по заданию ЦК КПСС и ЦК ВЛКСМ через туристские группы проводил политические интересы (Криворученко, 1964). О методах идеологической обработки иностранцев подробно рассказывается в коллективной монографии «Советское зазеркалье. Иностранный туризм в СССР в 1930-1980-е годы» (Багдасарьян и др., 2007). При этом туристские организации были освобождены от уплаты подоходного налога и других обложений, им предоставлялись государственные банковские кредиты на льготных условиях и скидки с транспортных тарифов (Абуков, 1983).

Понятно, что в своей работе БММТ «Спутник» действовало согласно решениям КПСС, Советского правительства, законодательства СССР, постановлениями ЦК ВЛКСМ и другим нормативным актам того времени, обеспечивая их соответствующее применение. Заметим, что в Конституции СССР право граждан Советского Союза на отдых обеспечивалось «... развитием массового спорта, физической культуры и туризма» (Конституция ... , 1988). в то время, как в Конституции Российской Федерации термин «туризм» отсутствует, хотя, конечно же туризм подразумевается, когда в этом главном законодательном документе страны говорится о праве граждан на отдых, право свободно передвигаться и о создании условий, обеспечивающих достойную жизнь и свободное развитие человека (там же).

Все эти тенденции создали предпосылки к более тесному взаимодействию с основной функциональной направленностью главным комсомольским штабом и, таким образом, в 1970 году БММТ «Спутник» Постановлением ЦК ВЛКСМ от 12 ноября 1970 года было реорганизовано и стало функционировать как подразделение ЦК ВЛКСМ. При этом реорганизованной молодежной туристской организации было предоставлено право решать вопросы развития международного и внутреннего туризма, осуществлять финансовую и хозяйственную деятельность от имени ЦК ВЛКСМ и представлять комсомол в международных туристских организациях (Столяренко, 1988: 5).

В 1980-е годы БММТ «Спутник» стало крупнейшей не только в СССР, но и в мире молодежной туристской организацией. Получила развитие и материально-техническая база организации. Была сформирована разветвленная сеть отделений БММТ «Спутник» во многих городах, республиках и областях Советского Союза. Так, на начало 1988 года в систему молодежного туризма ВЛКСМ входили 218 республиканских, краевых, областных и городских туристских подразделений, 19 туристских центров, 5 гостиниц. 
БММТ «Спутник» выступал инноватором по многим направлениям туризма. В то время еще не было интернета, однако уже тогда, в 1980-х годах в этой молодежной организации появились идеи и предложения по внедрению вычислительной техники в процесс туристского обслуживания и координации туристской деятельности. Началось внедрение специализированной информационно-вычислительной системы «Спутник», включавшей в себя сеть взаимосвязанных вычислительных центров и персональных электронно-вычислительных машин (ЭВМ), установленных как в головной организации, так и в региональных подведомственных отделениях. В штатном расписании подразделений «Спутника» появились должности инженеров-программистов и эксплуатационников ЭВМ. Эта система была предназначена для автоматизации перспективного и оперативного планирования деятельности Бюро, текущего контроля и взаимодействия с партнерами и поставщиками услуг. Для аппаратных работников «Спутника» начали проводиться теоретические и практические занятия по овладению навыками пользования вычислительной техникой. Сегодня все эти функции легко выполняются работниками с помощью специального программирования и разнообразных приложений, интегрированных в глобальную сеть Интернет, однако, полагаем, что все же уместно сегодня вспомнить, как все это начиналось в туризме несколько десятилетий назад.

Впечатляют объемы и география обслуживания на туристских маршрутах «Спутника», основные показали которых приходятся на внутрисоюзные маршруты. Именно здесь проходила основная работа комитетов комсомола по идейно-политическому, патриотическом и нравственному воспитанию молодежи. С рождением Новой России в 1992 году идеологическая надстройка в туризме исчезла, но остались качественные технологии и профессионализм в обслуживании туристов и экскурсантов, которые были заложены еще в советский период.

Динамика туристских показателей обслуживания по стране показывала хороший прирост от года к году: в 1979-1963 гг. по туристским программам «Спутника» прошли и проехали 14 млн человек, в 1983-1987 гг. — 16,5 млн человек. Маршруты «Спутника» привлекали разнообразием видов и форм организации путешествий. Это и многодневные железнодорожные путешествия в самые дальние уголки огромной страны, маршруты выходного дня, морские и речные круизы по Черному и Белому морям, по Волге, Енисею, Лене, Оби, Иртышу, Днепру, Дону, Амуру, Каме, Ладожскому и Онежским озерам.

Свыше 50 тыс. юношей и девушек отдыхало на плавучих туристских базах, а по железнодорожным маршрутам ежегодно отправлялось около 100 туристско-экскурсионных поездов, в которых путешествовали свыше 
Научные труды Московского гуманитарного университета 2018 № 6

36 тыс. туристов только по маршрутам выходного дня. Активно развивались автобусные путешествия и экскурсии в различных регионах Советского Союза. Своей деятельность «Спутник» охватывал и семейный отдых молодежи, в т. ч. родителей с детьми, что, как известно, благоприятно влияет на укрепление молодой семьи.

Особое внимание уделялось организации туризма с активными способами передвижения: пешеходным, водным, лыжным походам с ночевкой в палатках, самостоятельным приготовлением пищи и всем комплексом романтических приключений в природной среде.

Туристская работа «Спутника» была прочно связана с воспитательной работой с молодежью: в ходе реализации туристских программ организовывались встречи с выдающимися людьми, ветеранами войны и труда, проводились конкурсы и викторины с журналами «Турит» и «Смена», туристскими путевками поощрялись лучшие ученики школ и студенты. Накапливался богатейший опыт учебных экскурсий для обучающихся в школах и вузах. При этом эффективно реализовывались возможности туристских центров и молодежных лагерей. Первый такой центр - Крымский «Спутник» — был открыт еще в 1958 году.

В конце 1980-х гг. организация располагала двенадцатью международными лагерями и турцентрами из девятнадцати, а также несколькими гостиницами в Москве, Киеве, Одессе, в не только в Европейской части страны, но и в Сибири (г. Новосибирск), на Дальнем Востоке (Приморский край). Сетью туристских маршрутов «Спутника» была охвачены самые разные регионы - от Калининграда до Находки и от Мурманска до Душанбе.

Большая работа проводилась, безусловно, в многочисленных региональных отделениях «Спутника», благодаря чему деятельность этой замечательной и уникальной организации стала частью истории России. Так, в своей диссертации на соискание звания кандидата исторических наук А. С. Рубаник, изучавший историю развития туристско-экскурсионной деятельности в Орловской области подробно, с использованием большого количества архивных материалов описывает деятельность БММТ «Спутник» на территории Орловской области.

Диссертация А. С. Рубаника на тему «История развития туристско-экскурсионной деятельности в Орловской области в 1945-1985 гг.» была успешно защищена в диссертационном совете Московского гуманитарного университета в 2013 году. В своем диссертационном исследовании А. С. Рубаник отмечает, что 1970-е гг. в Орловской области интенсивное развитие получил международный молодежный туризм. Этому в значительной степени способствовало учреждение в 1973 г. отделения БММТ «Спутник» Орловского обкома ВЛКСМ. 
До учреждения Орловского отделения БММТ «Спутник» организацией международных туристских обменов молодежи активно занимались комсомольские организации области. В течение 1971 г. по туристским путевкам за границу было направлено 307 юношей и девушек (из них 286 чел. в социалистические страны, 21 чел. - в капиталистические). При утверждении групп туристов особое внимание уделялось их качественному составу.

Так, в отчете Орловского обкома ВЛКСМ об итогах туристского сезона 1971 г. отмечалось, что из 307 чел., направленных за рубеж 88 чел. являлись членами КПСС, 211 чел. - членами ВЛКСМ. Отмечалось при этом, что все участники путешествий за границу проходили идеологическую подготовку: туристы изучали права и обязанности советских граждан; основные вопросы, касающиеся государственного устройства СССР, деятельности государственных органов, организаций образования, здравоохранения и социального обеспечения; правила поведения за рубежом; а также получали сведения о политическом и государственном устройстве страны, в которую выезжали, об основных молодежных организациях и «их позициях в международном движении». При подготовке групп туристов, выезжающих в страны капиталистического блока, практиковалось проведение «имитаций политических дискуссий», целью которого являлась оценка «пропагандистских способностей кандидатов на выезд» (Рубаник, 2013: 151).

С момента создания Орловского отделения БММТ «Спутник» в области отмечен ежегодный рост объемов молодежного туристского обмена в среднем на 14-18 \%. Только за первый год работы по линии бюро было обслужено более 7800 чел. Из них: принято на территории Орловской области - 4097 советских туристов и 258 иностранных; направлено на внутрисоюзные маршруты - 3499 чел.

Туристские обмены осуществлялись на основе долгосрочных договорных документов и ежегодно заключаемых протоколов о сотрудничестве. В страну ежегодно приезжали активисты союзов молодежи Франции, Бельгии, Италии, Великобритании, Ливана, Финляндии, Австрии и др.

Для приема и размещения иностранных туристов в г. Орле БММТ «Спутник» использовало гостиничную базу города, общежития профтехучилищ и школ-интернатов, кемпинги «Зеленая Дубрава», профилакторий «Строитель», базу отдыха «Мечта» и мотель ВАО «Интурист» «Шипка». Все группы туристов обеспечивались собственными автобусами БММТ «Спутник» и автобусами ПАТП г. Орла. Питание туристов производилось в столовых Орловского треста столовых, а также в кафе, ресторанах г. Орла и области.

Экскурсионное обслуживание осуществляли экскурсоводы Орловского бюро путешествий, музеев области, Орловского отделения ВАО «Интурист», а также сотрудники предприятий и строек области. Прием туристов 
в г. Орле осуществлялся по 2-5 и однодневным программам. Разработка туристскими организациями типовых программ и стандартных маршрутов позволяла практически спланировать программу на долгосрочный период, давала возможность увеличивать информационную и идеологическую насыщенность (Рубаник, 2013: 153).

Огромной популярностью пользовалась у молодежи туристская экспедиция «Моя Родина СССР» как составная часть Всесоюзного похода комсомольцев и молодежи по местам революционной, боевой и трудовой славы советского народа (Рогатин, Квартальнов, Ухов, 1976: 17). Весь этот богатейший опыт можно использовать и сегодня, т. к. молодежи всегда нужны четкие и ясные ориентиры и идеалы, путь к понимаю которых сегодня несколько замутнен завесой из избыточных хаотичных потоков информации, которую надо учиться правильно воспринимать, анализировать и оценивать. Туризм и путешествия помогают молодежи лучше и глубже увидеть мир и себя в этом мире.

\section{СПИСОК ЛИТЕРАТУРЫ}

Абуков, А. Х. (1983) Туризм на новом этапе. Социальные аспекты развития туризма в СССР. М. : Профсиздат.

Багдасарян, В. Э., Орлов, И. Б., Шнайдген, Й. Й., Федулин, А. А., Мазин, К. А. (2007) Советской зазеркалье: Иностранный туризм в СССР в 1930-1980-е годы. М. : Форум.

Конституция (Основной Закон) Российской Федерации (1993). М.

Конституция (Основной Закон) Союза Советских Социалистических Республик (1988). М. : Известия.

Криворученко, В. К. (1964) Месяц в штатах : (Путевые заметки). М. : Молодая гвардия. 96 с.

Рогатин, Б., Квартальнов, А., Ухов, В. (1976) Орбита «Спутника». М. : Молодая гвардия.

Рубаник, А. С. (2013) История развития туристско-экскурсионной деятельности в Орловской области в 1945-1985 гг. : дисс. ... канд. ист. н. М.

Столяренко, Л. Э., Коидзе, Ж. Г. (1988) Развитие молодежного туризма в СССР. М. : Высшая комсомольская школа при ЦК ВЛКСМ.

Дата поступления: 30.08.2018 г.

Путрик Юрий Степанович - доктор исторических наук, профессор, заведующий кафедрой туризма и гостиничного дела Московского гуманитарного университета, вице-президент Международной туристской академии. Адрес: 111395, Россия, г. Москва, ул. Юности, д. 5. Тел.: +7 (499) 374-7956. Эл. адрес: putrik@list.ru 
Putrik Yuriy Stepanovich, Doctor of History, Professor, Head, Department of Tourism and Hospitality, Moscow University for the Humanities; Vice-President, International Tourist Academy. Postal address: 5, Yunosti St., Moscow, Russian Federation, 111395. Tel.: +7 (499) 374-79-56. E-mail: putrik@list.ru

\section{Для цитирования:}

Путрик Ю. С. Туристическое бюро «Спутник»: роль в развитии международных молодежных обменов [Электронный ресурс] // Научные труды Московского гуманитарного университета. 2018. № 6. URL: http://journals. mosgu.ru/trudy/article/view/838 (дата обращения: дд.мм.гг.). DOI: 10.17805/ trudy.2018.6.7 